\title{
DEVELOPING DIVISITE (DISCOVERY LISTENING WEBSITE) TO FACILITATE STUDENTS' LEARNING IN LISTENING SUBJECT
}

\author{
Muhammad Fajar Hidayat ${ }^{1}$, Dwi Putri Hartiningsari ${ }^{2}$ \\ ${ }^{1,2}$ STKIP PGRI Trenggalek, Trenggalek, Indonesia \\ ${ }^{1}$ hidatefajar@gmail.com, ${ }^{2}$ poetry.nink15@gmail.com
}

\begin{abstract}
This research aimed to develop DIVISITE (Discovery Listening Website) and facilitate students' learning of the listening subject. The design of this research was educational R\&D. The subjects of this study were the second-semester English Department students of STKIP PGRI Trenggalek for the academic year 2020/2021. The research procedure included needs analysis, studying education theories, developing the educational product, validating the product to experts, and field-testing. By using the website and combining it with the three stages in the Discovery Listening technique, it increased students' learning motivation and comprehension toward listening material. It was seen from the results of pre-motivation which obtained a score of 1051 (almost disagree). This implied that respondents rarely planned listening learning activities. Then, the results of the post-motivation questionnaire obtained a score of 1810 (almost agree). Thus, there was an increase related to students' learning motivation in listening by using the Discovery Listening Website. In conclusion, this research successfully developed DIVISITE (Discovery Listening Website) and facilitated students' learning in listening. Furthermore, this research was able to achieve the research objectives, namely DIVISITE (Discovery Listening Website), to facilitate students learning in the listening subject.
\end{abstract}

Keywords: discovery listening technique, web, listening

\section{PENGEMBANGKAN DIVISITE (DISCOVERY LISTENING WEBSITE) UNTUK MEMFASILITASI BELAJAR MAHASISWA PADA MATA KULIAH LISTENING}

\begin{abstract}
ABSTRAK
Tujuan dari penelitian ini adalah untuk mengembangkan DIVISITE (Discovery Listening Website) dan memfasilitasi pembelajaran mahasiswa pada mata kuliah listening. Desain penelitian ini adalah R\&D pendidikan. Subyek penelitian ini adalah mahasiswa semester dua Jurusan Bahasa Inggris tahun ajaran 2020/2021 STKIP PGRI Trenggalek. Prosedur penelitian meliputi analisis kebutuhan, mempelajari teori-teori kependidikan, mengembangkan produk, validasi produk kepada ahli, dan tes lapangan pada produk. Dengan menggunakan website dan dipadukan dengan tiga tahapan dalam teknik Discovery Listening, dapat meningkatkan motivasi belajar siswa dan pemahaman terhadap materi listening. Hal ini dapat terlihat dari hasil Pra motivasi memperoleh skor 1051 (hampir tidak setuju). Artinya, responden jarang merencanakan kegiatan pembelajaran menyimak. Kemudian, hasil angket pasca motivasi memperoleh skor 1810 (hampir setuju). Artinya, ada peningkatan yang berhubungan dengan motivasi belajar siswa dalam pembelajaran mendengarkan dengan menggunakan Discovery Listening Website. Kesimpulannya, berdasarkan temuan penelitian yang telah dijelaskan di atas. Penelitian ini telah mampu mengembangkan DIVISITE (Discovery Listening Website) dan memfasilitasi pembelajaran siswa dalam mendengarkan. Selanjutnya penelitian ini mampu mencapai tujuan penelitian yaitu DIVISITE (Discovery Listening Website) untuk memudahkan pembelajaran siswa dalam mata kuliah listening.
\end{abstract}

Kata Kunci: teknik discovery listening, web, mendengarkan

\begin{tabular}{|c|c|c|}
\hline Submitted & Accepted & Published \\
\hline 01 Juli 2021 & 09 Agustus 2021 & 24 Januari 2022 \\
\hline
\end{tabular}

\begin{tabular}{|l|l|l|l|}
\hline Citation & $:$ & $\begin{array}{r}\text { Hidayat, M.F., \& Hartiningsari, D.P. (2021). Developing DIVISITE (Discovery Listening Website) to Facilitate Students' } \\
\text { Learning in Listening Subject. Jurnal PAJAR (Pendidikan dan Pengajaran), 6(1), 01-11. DOI: } \\
\text { http://dx.doi.org/10.33578/pjr.v6i1.8458. }\end{array}$ \\
\hline
\end{tabular}

\section{INTRODUCTION}

Listening is a way to develop language skills, especially in education. For students, it is important to need listening skills so that they can listen to something more effectively so that in developing language skills they can listen effectively even when faced with unfamiliar vocabulary or structures. Listening in language learning is important because it is impossible for someone to always want to repeat what they say if we don't understand what they say to us. In 
language learning, students must know and understand what other people say to them. Brown (2001: 247) states that "Listening is a major part of language learning and teaching because in the classroom students listen more than they speak." That is, the importance of listening to one of the important things in everyday life and from listening we can interpret its meaning. In listening to this understanding, listeners must understand and grasp the idea of what they are hearing. For that, a Discovery Listening Technique (DLT) is needed so that the listening comprehension process becomes easier when we practice.

Discovery listening is one technique for improving students comprehension in learning listening. As Hartiningsari (2018) found that by implementing three phases of Discovery listening technique, the students could improve their listening skill. Futher, according to Wilson (2003), the Discovery Listening Technique (DLT) using a process-based approach that encourages students to learn how to listen by paying attention to the causes of listening difficulties during listening and ultimately increasing awareness of how to overcome the difficulties they find. It also supported by Baehaqi (2016) who states that the Discovery Listening is used to show students the mental activities they do to build their understanding of listening texts. This technique pays balanced attention to meaning and form which requires students to reconstruct the text they hear and makes them more aware of perceptual difficulties during the comprehension process. The listening discovery task has three phases: listening, reconstructing, and discovering. The listening phase has three stages; 1) Students only listen to short texts which are spoken at normal speed, 2) They self-assess their level of understanding after listening, 3) They listen to it two more times along with taking notes. Furthermore, at the reconstruction stage, the listener must form small groups and use their notes and try to reconstruct the original text together. Then the discovering stage has three stages: first, students compare their reconstructed text with the original and try to classify the reasons for their error, and then they judge the relative importance of their mistakes, and finally listen again without reading the text, and judge their performance. The existence of DLT can be more useful when it is combined with technology.

Nowadays, technology is needed in learning in today's era to make learning easier. All existing technologies and the resulting educational technology products must be selected and built based on an analysis of the needs of a particular learning environment. Januszewski (2007) states the definition of educational technology according to AECT (The Association for Education Communications \& Technology), educational technology is the study and ethics of practice to facilitate learning and improve performance by creating, using, and managing appropriate technological processes and resources. Moreover, the use of e-learning is highly recommended for technology in learning. Soekartawi (2002) states that e-learning is a general term for all technologysupported learning using a variety of teaching and learning tools such as telephone lines, audio, and video recording, teleconferencing, satellite transmission, and more commonly known webbased training or computer-based instruction also commonly referred to as courses online.

E-learning can bring a new atmosphere in a variety of learning development, and the benefits of e-learning are that it can increase students' absorption of the material being taught, it can improve student learning abilities independently. So, this study using website-based media. Hartono (2014) explains that Web or it can be called the Website can be interpreted as a collection of pages that display information such as text data, still or moving images, animation, sound, video, and a combination of all that is static or dynamic. To form one interrelated series where each one is connected to a network - network or can be called a hyperlink. There are many advantages of learning by using the media of a website proposed by Rusman and Cepi Riyana (2012:271), including: allows anyone, anywhere, anytime, to learn anything, the ability to create links, so that learners can access information from various sources, potential as a learning resource for learners who do not have enough time to study, can encourage learners to be more active and independent in learning, content, and materials can be updated easily. It is also supported by Hartiningsari et al. (2019) who explained that 
students use internet more often than printed books, for solving this condition, optimalizing technology in a form of learning media based internet should be developed.

Based on the background described above, the statement of this research is how to develop DIVISITE (Discovery Listening Website) to facilitate students' learning in listening? The purpose of this research is to develop DIVISITE (Discovery Listening Website) and facilitate students' learning in listening subject.

\section{LITERATURE REVIEW}

Rost (2002:279) states that listening is a mental process of constructing meaning from verbal input. Rost also said that listening is very important in language classes because it provides input for students. For this reason, Discovery Listening Technique (DLT) is needed so that the process of understanding listening becomes easier when they practice.

Wilson (2003) explains that Discovery Listening Technique (DLT) uses a process-based approach that encourages students to learn how to listen by noticing causes of listening difficulty during listening and finally raising awareness of how to cope with these difficulties found. Further, Baehaqi (2016) defines discovery listening to be used to show students the mental activities they do to build their understanding of the listening text. Therefore, we need a learning media containing Discovery Listening Techniques to build their understanding of listening texts.
Next, Ginting et al. (2015) state that learning media plays an important role in supporting the achievement of learning objectives. The media used in learning is a website. Further, Hartono (2014) states the web or it can be called the Website can be interpreted as a collection of pages that display information such as text data, still or moving images, animation, sound, video, and a combination of all that is static or dynamic to form one interrelated series where each one is connected to a network - network or can be called a hyperlink.

\section{REASERCH METHOD}

The research utilized Research and Development (R\&D) research design. Basuki (2019: 21) defines "educational R\&D as a research design that aims to develop educational products, such as curriculum, syllabus, textbooks, learning media, etc.". The research and development procedure for making and developing as a learning medium consists of the following processes: needs analysis, studying the latest educational theory, developing the educational products, validating products to experts, field - testing the product (Adapted from Mukti \& Basuki, 2020: 84). In field testing of this product, the researcher uses four stages, namely planning, implementing actions, observing, and reflecting. The following table shows the development steps of the product in this research.

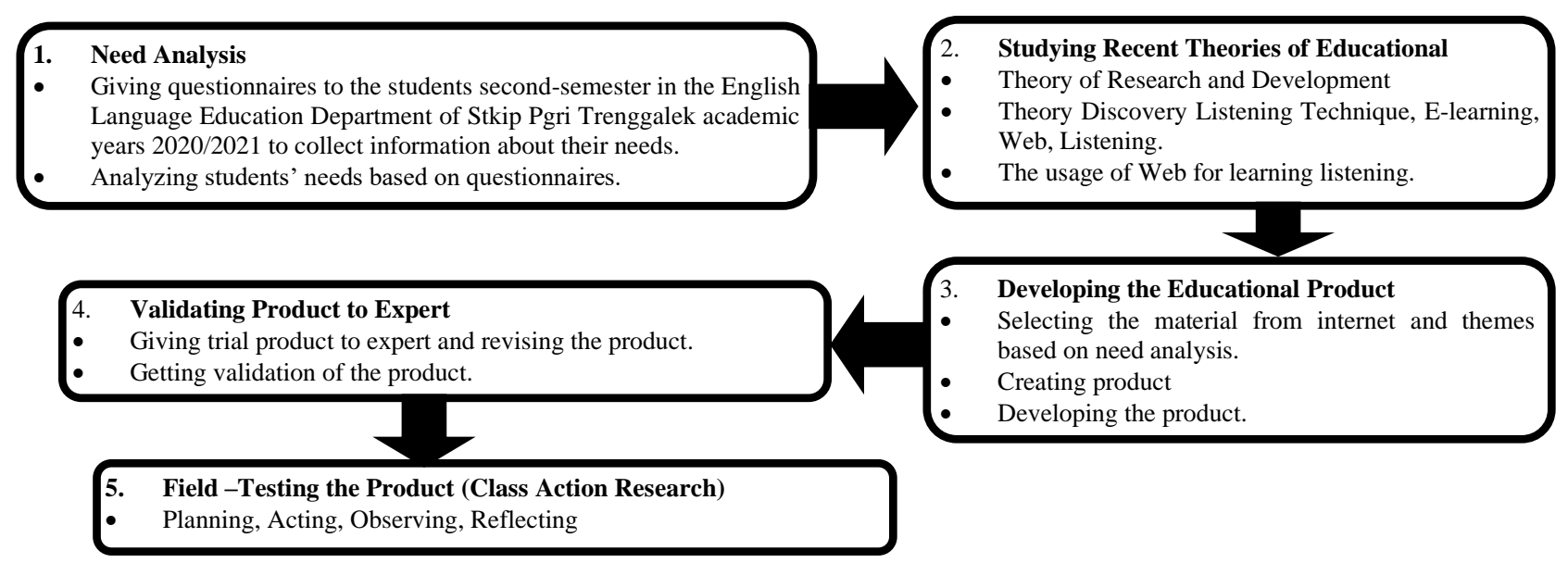

Figure 1. Development Steps of DIVISITE 
The researcher conducts the research started from 24 $4^{\text {th }}$ November 2020 in English Language Department of STKIP PGRI Trenggalek that consists of 30 students.

In this study, the researcher used interviews, questionnaires, and field notes to collect data. The Researcher used face-to-face interviews to find out the opinions or suggestions of listening subject teachers before making listening learning products and evaluating from experts at the time of product validation. After that, the results are used for product refinement before being tested in the field. Then, the researcher used a Likert scale to collect the data questionnaire which had a five-point scale to state the level of conformity with the following statements; strongly disagree, disagree, neutral, agree, and strongly agree. The researcher used a closed-ended questionnaire consisting of needs analysis, prequestionnaire, student feedback, and postquestionnaire with five alternative answers. The needs analysis questionnaire consists of 15 questions then, it is distributed to students before making the product. Furthermore, the prequestionnaire consists of 15 questions then is distributed to students before using the product. Student feedback consists of 16 questions then, it is distributed to students after trying to use the product. The post-questionnaire consists of 15 questions then is distributed to students after using the product. The researcher used field notes as notes describing the stages of this learning development process.

Furthermore, in the data analysis method, the researcher uses SPSS for Windows version 25 to know the validity and reliability of instruments. In the validity test, all questionnaires resulted in the values of Pearson Product Moment correlation more than $0.350(>0.30)$ and declared valid (Andresen in Anisah (2018: 33)). Then, in the reliability test, all questionnaires resulted in the values Alpha Cronbach more than $0.903(>0.60)$ and declared have good reliability (Sekaran and Bougie in Muldyagin (2018: 18)). Further, the data analysis of the interview was analyzed qualitatively. Then, the data analysis of all questionnaires was analyzed quantitatively by using the Likert Scale. Syofian et al. (2015: 6) confirms that the Likert Scale data can be analyzed by summarizing the respondents' scores, then looking for the criteria. The data assessment uses the following: 1 (strongly disagree), 2 (disagree), 3 (neutral), 4 (agree), and 5 (strongly agree). Then, the researchers sum the collected data with $\mathrm{Q}$ for number of questions and $\mathrm{N}$ for number of the respondent; the researchers find the score criteria based the formula in following figure.

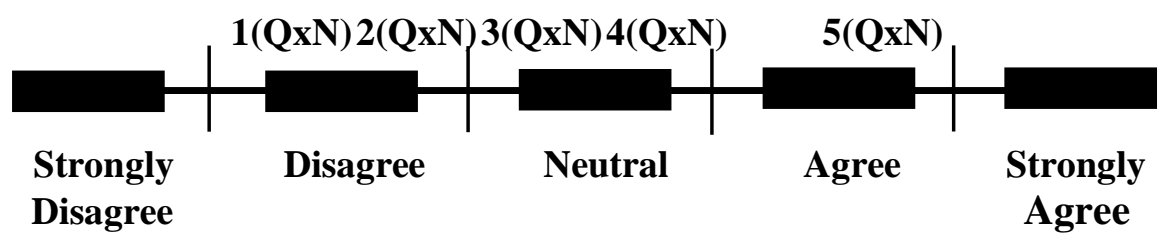

Figure 2. Continuum Diagram of Students' Questionnaire Result

\section{RESULTS AND DISCUSSION}

This section discusses the results of research including finding of initial product development, finding of expert validation, and finding of product field-testing.

\section{Finding of Initial Product Development}

From the students' needs analysis questionnaire collected from 30 respondents, the total score is 1765 . To interpret the data, the researchers count maximum score $(5 \times 15 \times 30)=$ 2250 , minimum score $(1 \times 25 \times 30)=450$, score range $(2250-450)=1800$, total score $=1765$ and resulted the following figure. 


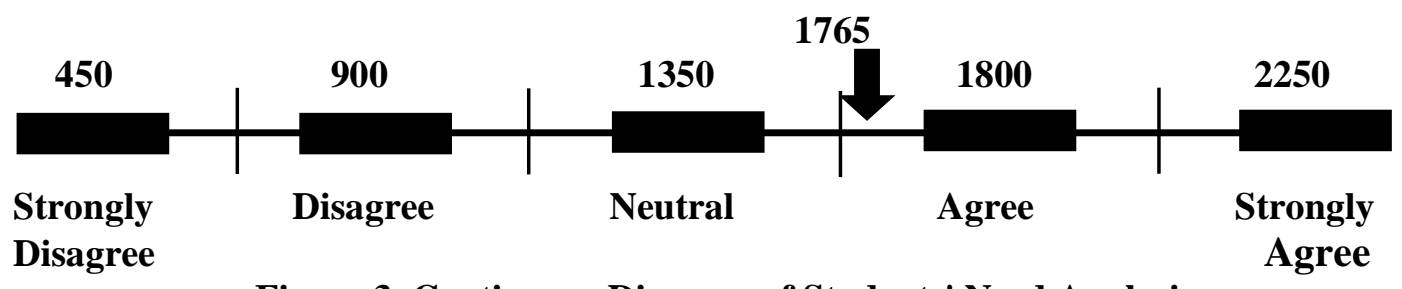

As a student's need to study listening subjects. Most students agree that a learning website is needed to motivate them to study listening course material. Furthermore, most students chose to agree that listening learning media were needed with topics that were interesting, easy to operate, easy to understand, small learning media sizes, and cheap criteria. The results showed that most of the students agreed with the product development in this study. Then it can be used as basic information for website development in involving students when learning listening subject material that meets the product development theory framework including students' perceptions of learning the listening subject matter.

\section{Finding of Expert Validation}

Before field-testing the product, the researcher validated the product to learning media expert and listening material expert. Here is the detail:

Table 2. Product Comparison Before and After Validating to Learning Media Expert

\begin{tabular}{lll}
\hline \multicolumn{2}{c}{ Before } & \multicolumn{1}{c}{ After } \\
\hline - The validation form does not match the stages & $\bullet$ The validation form is in accordance with the stages \\
- The bottom frame is not good enough & - The bottom frame is nice and fit \\
- The validation form is in accordance with the stages & $\bullet$ Validated \\
- The bottom frame is nice and fit & - Validated \\
\hline
\end{tabular}

Table 3. Product Comparison Before and After Validating to Listening Material Expert Before After

\begin{tabular}{|c|c|}
\hline $\begin{array}{l}\text { - Already in accordance with the stages of the } \\
\text { Discovery Listening Technique } \\
\text { - This product conforms to the sufficiency, clarity, } \\
\text { and depth of the material }\end{array}$ & $\begin{array}{l}\text { - } \quad \text { Validated } \\
\text { - } \quad \text { Validated }\end{array}$ \\
\hline
\end{tabular}

The following image shows the characteristics, content, and characteristics of product development. 


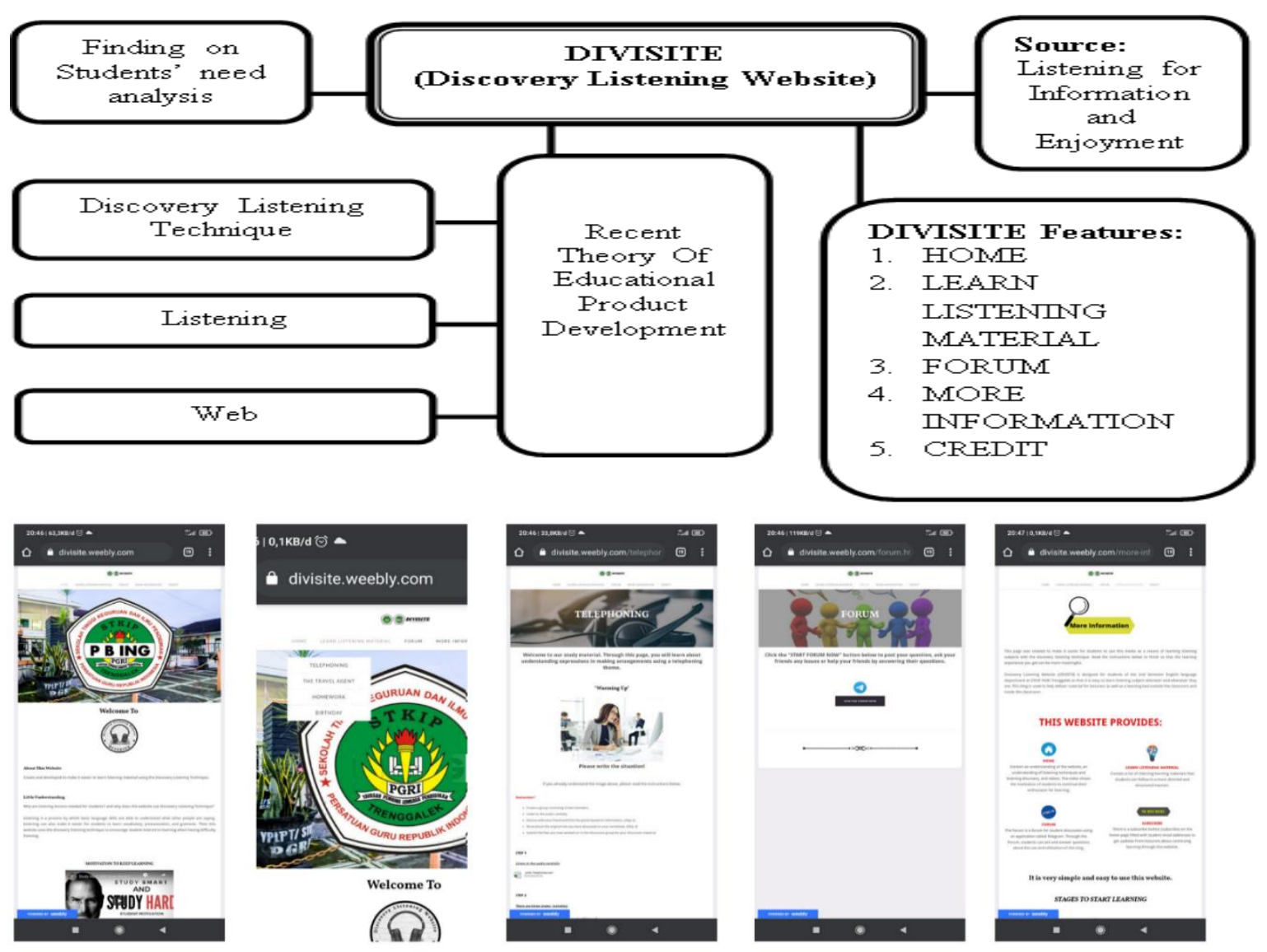

Figure 4. Characteristic, Contents and Features of the Product of Research Development

The development of this research product is based on the results of students' needs, the latest theories related to the product, the adaptation of content consisting of listening subject matter with the Discovery Listening Technique stage. Then a DIVISITE (Discovery Listening Website) was developed as a learning website for listening subjects.

This research resulted in a listening learning website, and it was named Discovery Listening Website (DIVISITE). It was created using weebly.com. DIVISITE was designed using three steps of discovery listening, namely: first, students could understand the listening subject matter because the listening subject matter could be repeated. Second, students can reconstruct the text back from the results of discussions with their friends. Third, students can develop reconstructed texts with their friends. DIVISITE can be accessed easily using a PC, laptop, or smartphone, provided there is an internet network / WI-FI network.

\section{Finding of Field-testing Product}

The field test product is the final step in developing a website that engages students in learning listening subjects while using DIVISITE. It is used to investigate the application of the product in real situations. Here is the result:

\section{a. Process of Planning}

The researcher designed distance learning lesson plans to involve students in listening learning. RPPD is made in according to the second semester study contract for the English Language Education Department of STKIP PGRI Trenggalek academic years 2020/2021. 


\section{b. Process of Acting}

The researcher distributed pre-motivation questionnaires before using DIVISITE. From the pre-motivation questionnaires collected from 30 respondents, the total score is 1051 . To interpret the data, the researchers count maximum score $(5$ $\mathrm{x} 15 \times 30)=2250$, minimum score $(1 \times 15 \times 30)=$ 450 , score range $(2250-450)=1800$, total score $=$ 1051 and resulted the following figure.

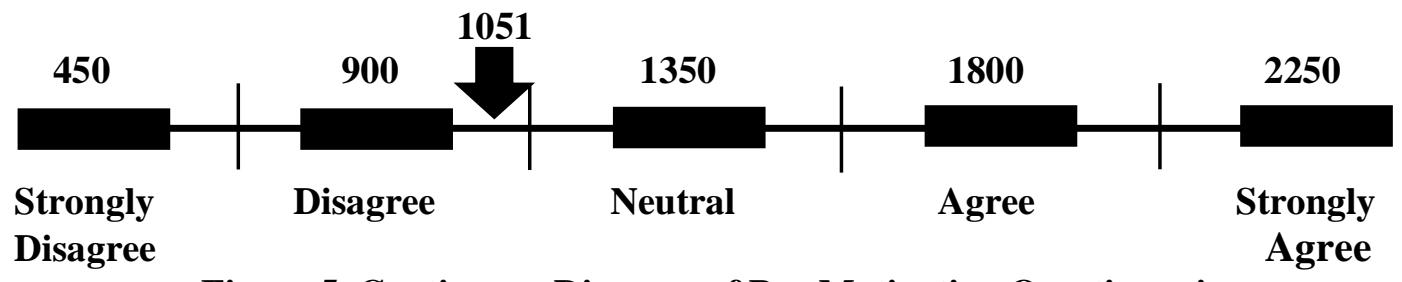

Figure 5. Continuum Diagram of Pre-Motivation Questionnaire

Furthermore, the researcher did what had been planned in the previous planning stage, namely using DIVISITE four meetings in teaching and learning activities during distance learning and described in the following table.

Table 4. Online learning while using DIVISITE

\footnotetext{
- The use of DIVISITE to listen the audio material Telephoning

- The use of DIVISITE to assess the level of understanding of students by looking for points in the audio

- The use of DIVISITE to reconstruct the original text from the audio

- The use of DIVISITE to discovering the compare their reconstructed text with the original, and attempt to classify the reason of their mistakes.
}

\section{Meeting one}

- During online learning, students use DIVISITE to listen to the audio material provided

- During distance learning, students use DIVISITE to assess their level of understanding by looking for points in the audio.

- During distance learning, students use DIVISITE to reconstruct the original text from the audio using notes they have written correctly.

- During distance learning, students use DIVISITE to discover and compare their reconstruction text with the original, attempt to classify the reason of their mistakes, and conclude the material their discuss.

\section{Meeting two}

- The use of DIVISITE to listen the audio material The Travel Agent

- The use of DIVISITE to assess the level of understanding of students by looking for points in the audio material

- The use of DIVISITE to reconstruct the original text from the audio material

- The use of DIVISITE to discovering the compare their reconstructed text with the original, and attempt to classify the reason of their mistakes.
- During online learning, students use DIVISITE to listen to the audio material provided

- $\quad$ During distance learning, students use DIVISITE to assess their level of understanding by looking for points in the audio.

- During distance learning, students use DIVISITE to reconstruct the original text from the audio using notes they have written correctly.

- During distance learning, students use DIVISITE to discover and compare their reconstruction text with the original, attempt to classify the reason of their mistakes, and conclude the material they discuss.

- The use of DIVISITE to listen the audio - During online learning, students use DIVISITE to listen to material Homework the audio material provided

- The use of DIVISITE to assess the level of understanding of students by looking for points in the audio material

- During distance learning, students use DIVISITE to assess their level of understanding by looking for points in the audio. 
- The use of DIVISITE to reconstruct the original text from the audio material

- The use of DIVISITE to discovering the compare their reconstructed text with the original, and attempt to classify the reason of their mistakes.

\footnotetext{
- The use of DIVISITE to listen the audio material Birthday

- The use of DIVISITE to assess the level of understanding of students by looking for points in the audio material

- The use of DIVISITE to reconstruct the original text from the audio material

- The use of DIVISITE to discovering the compare their reconstructed text with the original, and attempt to classify the reason of their mistakes.
}

\section{c. Process of Observing}

The researcher distributes field notes to observe and monitoring the activeness of students through the "FORUM" to find out whether they were learning listening lessons using DIVISITE or not. During the observation, starting from the first
- During distance learning, students use DIVISITE to reconstruct the original text from the audio using notes they have written correctly.

- During distance learning, students use DIVISITE to discover and compare their reconstruction text with the original, attempt to classify the reason of their mistakes, and conclude the material they discuss.

Teeting four

- During online learning, students use DIVISITE to listen to the audio material provided

- During distance learning, students use DIVISITE to assess their level of understanding by looking for points in the audio.

- During distance learning, students use DIVISITE to reconstruct the original text from the audio using notes they have written correctly.

- During distance learning, students use DIVISITE to discover and compare their reconstruction text with the original, attempt to classify the reason of their mistakes, and conclude the material they discuss.

\section{Table 5. Field Notes result}

\section{Meeting one}

\section{THERE ARE OBSTACLES}

- It takes about 1-2 minutes to access the website (depending on signal network conditions and internet quota).

- The audio in the material sometimes downloads itself automatically (depending on the user of the device). meeting to the fourth meeting there were obstacles or no obstacles, which will be shown in the following table of field notes result. Thus, all observational activities were carried out by researcher.

\section{Meeting two

THERE ARE OBSTACLES

THERE ARE NO OBSTACLES

- It takes about 1-2 minutes to access the website • There are no obstacles when doing tasks on the website. (depending on signal network conditions and internet quota).

- The audio in the material sometimes downloads itself automatically (depending on the user of the device).

\section{Meeting three}

THERE ARE OBSTACLES $\quad$ THERE ARE NO OBSTACLES

- Some have not collected it in the form of .zip or .rar $\bullet \quad$ All safe folders.

\section{THERE ARE OBSTACLES}

Meeting four

- All Safe

- All Safe


d. Process of Reflecting

1) Process Evaluation of Reflecting

From the students' feedback questionnaires collected from 30 respondents, the total score is 1970. To interpret the data, the researchers count maximum score $(5 \times 16 \times 30)=$ 2400 , minimum score $(1 \times 16 \times 30)=480$, score range $(2400-480)=1920$, total score $=1970$ and resulted the following figure.

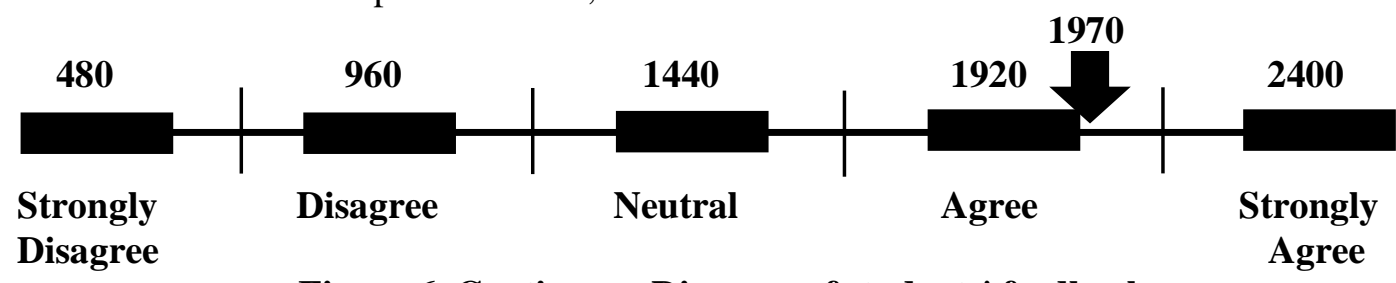

Figure 6. Continuum Diagram of students' feedback

Thus, students' feedback on the product was found. Most students are satisfied with the appearance or design of the initial appearance, layout, background, themes, motivational videos, and instructions in the product being developed. Furthermore, the contents of the students agreed that the audio on the website was following the material and was at the Discovery Listening Technique stage. In addition, according to students, this website can motivate them to study independently, especially in studying listening subjects.

\section{2) Result Evaluation of Reflecting}

From the post-motivation questionnaires collected from 30 respondents, the total score is 1810. To interpret the data, the researchers count maximum score $(5 \times 15 \times 30)=2250$, minimum score $(1 \times 15 \times 30)=450$, score range $(2250-450)$ $=1800$, total score $=1810$ and resulted the following figure.

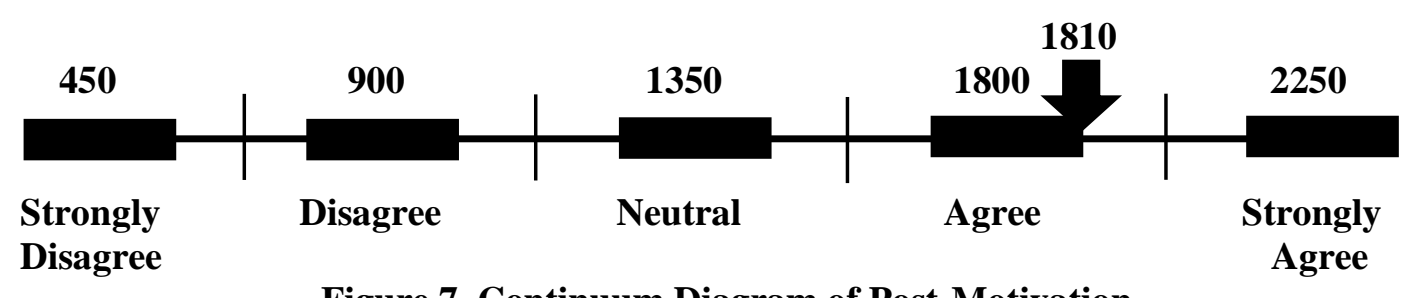

Given the research findings elaborated above, the discussion is highlighted to some points: first, regarding the product content in this study is an adaptation of the Discovery Listening Technique, which is about Wilson (2003), Discovery Listening Technique (DLT) using a process-based approach that encourages students to learn to listen by paying attention to the causes of listening difficulties while listening and finally raising awareness about how to overcome this difficulty was found. Second, concerning to the product development step in this research, the research technique (Adapted from Mukti \& Basuki, 2020: 84) that there are five steps: Need analysis, Studying Recent Theories of Educational, Developing the Educational product, Validating the product to expert, and Field-testing the Product. Third, concerning with the developing product DIVISITE was in line with students' need. Fourth, concerning to the applicability of the product that was tried out in Class Action Research design. Fifth, regarding the form of the product in this study, it is in line with Ginting et al. (2015) stated that learning media plays an important role in supporting the achievement of learning objectives. With the regard to those discussions of the finding and sound of theories, it can be said that the product in the form of developing DIVISITE (Discovery Listening Website) to facilitate students' learning in listening subject of English Language Department, was practically suitable with the sound of theories a regulation stated previously and 
the people who found the necessity of the product were satisfied with it.

\section{CONCLUSIONS AND RECOMMENDATION}

This research produced DIVISITE (Discovery Listening Technique Website) to facilitate students in learning listening subject. The application of this product is in a form of online learning . the application consists of some features. They are Home, Learn Listening Material (Discovery listening Technique stages), Forum, More Information and Credit. The first feature shows a brief explanation about listening and motivation. Second features shows listening material about telephoning, the travel agent, homework and Birthday. This features also employs the steps of Discovery listening techniques) in every material given. Third, Forum shows the button to post students' question, ask or discuss. Fourth, more information and credit.

The application was developed based on the students' need analysis, the material of Listening for Information and Enjoyment, evaluation and suggestion from the experts who validates the product. The findings of field testing show that the product increace students' motivation in learning listening material. They know material better using this product. The students agreed that the audio on the website was following the material and was at the Discovery Listening Technique stage. In addition, according to students, this website can motivate them to study independently, especially in studying listening subjects. Thus it can facilitate them to learn listening subject.

Given the findings, discussions, and conclusion elaborated above, it is recommendations for the following people who may find benefits of this research. Firstly, for students who want to increase their interest and listening skills in listening subjects, it is suggestive of using product of this research for learning medium so that students can easily learn listening subjects. Secondly, for lecturers who teach listening, it is suggestive of using the product of this research to make it easier for you to teach listening material to students. Thirdly, future researchers can use the results of this study as information and reference for their research.

\section{REFERENCES}

Anisah. (2018). An Ex Post Facto Analysis of the Comparison of Vocabulary Mastery between Using Pictures and Audio-Visual Media at Seventh Grade of Nahdhatul Islahiyah School, Narathiwat, Thailand. Universitas Muhammadiyah Gresik, 2938. htpp://eprints.uny.ac.id/33172/.

Arikunto, S. (2006). Penelitian Tindakan Kelas. Jakarta: PT Bumi Aksara.

Baehaqi, L. (2016). Improving the Listening Skills Through "the Discovery Listening Technique" Using Podcast. The Multifaceted Dimensions of English Linguistics, Literature and Education Literature and Education, (December 2016), 129-139. http://www.stainpalangkaraya.ac.id.

Basuki, Y. (2019). The Requisite Vocabulary 1 Material For College Students Of STKIP PGRI Trenggalek The Requisite Vocabulary 1 Material For College Students Of. (July 2019). www.researchgate.net/publication/334545 425_THE_REQUISITE_VOCABULAR Y 1 MATERIAL FOR COLLEGE ST UDENTS OF STKIP PGRI TRENGGALEK.

Brown, H. D. (2001). Teaching Principle Pedagogy. Addison Wesley Lingman, Inc.

Ginting, R., Harahap, F., \& Manurung, B. (2015). Pengaruh Penggunaan Media TIK Terhadap Retensi Memori Biologi Siswa Kelas XII SMA. Jurnal Pendidikan Dan Pembelajaran Universitas Negeri Malang, 22(2), 176-182. www.neliti.com/publications/122012/pen garuh-penggunaan-media-tik-terhadapretensi-memori-biologi-siswa-kelas-xiism.

Hartiningsari, D.P, (2018). Improving Listening Skill Through Discovery Listening Technique. Lingua-Litera,1(1),21-30. https://journal.stkippgritrenggalek.ac.id/in dex.php/kid/article/view/122.

Hartiningsari, D.P., Suprayitno, Marpinjur, T.R.(2019). Pengembangan Media Pembelajaran Discovery Berbasis Blog untuk Mata Kuliah Bahasa Inggris. Jurnal 
PAJAR (Pendidikan dan Pengajaran), 3(2), 237-247. DOI: http://dx.doi.org/10.33578/pjr.v3i2.6845.

Hartono, H. (2014). Pengertian Website dan Fungsinya. Ilmu Teknologi Informasi. http://ilmuti.org/wp-.

Januszewski, M. (2007). Educational Technology A Definition with Commentary (2nd Edition). Routledge.

Mukti, B \& Basuki, Y. (2020). VIVOICE: An Effort to Promote EFL Learners 'SelfRegulated Learning during the COVID-19 Outbreak VIVOICE. (Desember). DOI: 10.25273/etj.v8i6.7715.

Muldyagin, D. H. (2018). The Correlation between the Interest in Practicing English Conversation and Speaking Fluency of English Department Students of Pasundan University. 1-22. http://www.repository.unpas.ac.id/40125/.

Rost, H. (2002). Multimedia teaching with video clips: TV, movies, YouTube, and mtvin the college classroom. Teaching and Reseaching Listening. Longman Pearson Education, London (2002).

Rusman, C., \& Riyana, D. K. (2012). Pembelajaran Berbasis teknologi Informasi dan komunikasi: Mengembangkan Profesionalitas Guru (1st Edition). Jakarta : Rajawali Pers.

Soekartawi. (2002). Prinsip dasar e-learning: teori dan aplikasinya di Indonesia. Jurnal Tektodik, 12(vii), 3.

Syofian, S., Setiyaningsih, T., \& Syamsiah, N. (2015). Otomatisasi Metode Penelitian Skala Likert Berbasis Web. (November), $1-8$.

https://jurnal.umj.ac.id/index.php/semnast ek/article/download/540/506.

Wilson, M. (2003). Discovery listeningimproving perceptual processing. ELT Journal, 57(4), 335-343. DOI: 10.1093/elt/57.4.335. 